\title{
İslam Bilim Tarihi Üzerine İdealist Bir Bilim İnsanı Fuat Sezgin ve Yaşamı Üzerine Bir Değerlendirme
}

\author{
Fuat Sezgin An Idealist Scientist on The History of Islamic Science and An \\ Evaluation on His Life
}

\author{
Dr. Öğr. Üyesi Serdar SAYGILI (iD)1
}

\begin{abstract}
$\ddot{O} \mathbf{z}$
İslam bilim tarihiyle ilgili çalışmalarını temel İslam ilimlerinin ötesine taşıyan Fuat Sezgin; astronomi, coğrafya, meteoroloji, kimya, matematik, geometri, tıp, genetik, optik ve felsefe gibi alanlarda faaliyetler gerçekleştirmiştir. İslam bilim tarihi alanındaki çalışmaları ile bilimler tarihine yeni paradigmalar kazandırmıştır. Bu durum İslam bilimler tarihiyle ilgili bilinçli ve/veya bilinçsiz bir biçimde yok sayılan hakikatlerin ortaya çıkarılmasında önemli bir rol oynamıştır. Buna karşın Batı dünyasında ortaya çıkan Rönesans fikir hareketi, İslam medeniyetinin insanlığa katkısını nerdeyse yok saymıştır. Bu bağlamda makalemizin temel yazım amacı, tüm yaşamını İslam dünyasındaki bilimsel ve teknolojik faaliyetlerin objektif bir biçimde bilinmesine adayan Fuat Sezgin'i hayatı, eserleri, şahsiyeti ve insani değerleri üzerinden tanımaktır. Bu noktada çocukluğu, gençliği, olgunluk yılları, eğitim/öğrenim hayatı ve hayatındaki dönüm noktaları tespit edilecektir. Bununla birlikte Sezgin'in İslam bilim ve teknoloji tarihi üzerine yazdığı eserler tanıtılmaya çalışılacaktır. Sezgin'in günümüze kadar yazmış olduğu eserlerin türleri ve bilim dünyasına katkısı değerlendirilecektir. Eserleri ile İslam bilim ve teknoloji tarihi üzerinde mevcut ezberleri nasıl tartışmaya açtığı gösterilecektir. Ayrıca makalemizde, idealist bir bilim insanı Sezgin'in Türk-İslam kültürü ile yoğrulmuş ilkeli yaşantısı çerçevesinde gelişen şahsiyeti ve insani değerleri ortaya koyulacaktır. Böylece Fuat Sezgin'in hayatı, eserleri, şahsiyeti, insani değerleri ve idealleri ile şekillenmiş yaşam portresi bir bütün olarak sunulacaktır.
\end{abstract}

Anahtar Kelimeler: Hayatı, eserleri, şahsiyeti, değerleri, idealleri

Makale Türü: Derleme

\begin{abstract}
Fuat Sezgin who carries his work on the history of Islamic science beyond the basic Islamic sciences; worked in fields such as astronomy, geography, meteorology, chemistry, mathematics, geometry, medicine, genetics, optics and philosophy. With his works in the field of the history of Islamic science, he has brought new paradigms to the history of science. This situation played an important role in revealing the truths that were concealed in a conscious or unconscious way about the history of Islamic sciences. However, the Renaissance idea movement that emerged in the Western world almost ignored the contribution of Islamic civilization to humanity. In this context, the basic writing purpose of our article is, to recognize Fuat Sezgin in the context of his life, works, personality and human values. At this point, childhood, youth, maturity years, education/learning life and turning points in life will be determined. In addition, the works written by Sezgin on the history of Islamic science and technology will be introduced. The types of the works by Sezgin and their contribution to the scientific world will be evaluated. It will be shown how his works led to discussion on the history of Islamic science and technology. Furthermore, in this article, the personality and human values of Sezgin, an idealist scientist, blended with Turkish-Islamic culture will be revealed. So Fuat Sezgin's life, works, personality, human values and ideals will be presented as a whole portrait of life.
\end{abstract}

Keywords: Life, works, personality, values, ideals

Paper Type: Review

${ }^{1}$ Erciyes Üniversitesi, Edebiyat Fakültesi, serdarsaygili@erciyes.edu.tr.

Atıf için (to cite): Saygıll, S. (2019). İslam Bilim Tarihi Üzerine İdealist Bir Bilim İnsanı Fuat Sezgin ve Yaşamı Üzerine Bir Değerlendirme. Afyon Kocatepe Üniversitesi Sosyal Bilimler Dergisi, 21 (Prof. Dr. Fuat Sezgin Özel Sayıs1), 27-40. 


\begin{abstract}
"Fuat Bey, benim konum budur veya şudur demeyen adamlardan. Tersine, Fuat Bey problemin peşine giden bilim insanlarından. Efendim; ben Arabistim, ben bilim tarihçisiyim, bu veya şu beni ilgilendirmez demiyor. Ele aldiğı problem neyi gerektiriyorsa Fuat Bey onun peşine düşüyor. Fuat Bey imkân yokluğu diye bir kavram tanımayan bir insan. Peşine düştüğü şey Timbaktu'nun bilmem ne kütüphanesinde ise Fuat Bey onu bulup çıkartıyor. Bu davranışı körükleyen meraktır ki, bitip tükenmeyen merakı kanımca Fuat Beyin en önemli özelliğidir. Yetmiş dokuz yaşında iken beş yaşında bir çocuğun merakını kaybetmemiş bir insan Fuat Bey” (Şengör, 2004: 12).

Prof. Dr. Celal Şengör

"Fuat Sezgin'in bilim tarihine yeni bir boyut getiren eserleri ve görüşleri günümüz Íslam dünyası için ayrı bir önem taşımaktadır. Bu kültür çevresine unutmuş olduğu bilimsel geçmişini anımsatmak, yitirmiş olduğu belleğini yeniden kazandırarak bilimsel araştırma şevkini uyandırmak ve ona özgüven aşılamak gibi tarihi bir görevi yerine getirmektedir" (Sezgin, 2008 Önsöz'ünde: 10).

Prof. Dr. Engin Bermek
\end{abstract}

\title{
1. Hayatı
}

1924 y1lında Bitlis’te doğan Fuat Sezgin, ilkokulu Ağrı'nın Doğubayazıt ilçesinde bitirdikten sonra orta ve lise öğrenimine Erzurum ilinde devam etmiştir (Ekici, 2013: 391). 1943 yılında mühendislik fakültesine girmek için İstanbul'a gelen Sezgin, bir yakınının önerisiyle İstanbul Üniversitesi Şarkiyat Araştırmaları Enstitüsü'nde alanının önemli simalarından birisi olan Alman şarkiyatçı Prof. Dr. Helmut Ritter'in tarafindan sunulan konferansa katılmıştır. Ritter'in konferansından sonra mühendislik düşüncesinden vazgeçerek bilim tarihi üzerine öğrenim yapmaya karar vermiştir (İdin, 2018). Sezgin, yaşamının dönüm noktalarından birisi olan bu süreç ile ilgili olarak şu açıklamayı yapmıştır:

"1943 yılında akrabalarımdan birisi beni Edebiyat Fakültesine götürdü. Hâlbuki ben mühendis olma sevdası peşindeydim. O zaman büyük bir Alman âlim vardı. Arapçayı çok iyi bilirdi. Bana seni onun seminerine götürmek istiyorum dedi. Ben de gidelim dedim. $\mathrm{O}$, büyük âlimin seminerine gittim. O gün büyük âlim beni adeta büyüledi. Ben artık mühendis olmayı veya başka bir mesleğin peşinde koşmayı kafamdan çıkardım. O büyük âlimin talebesi olmayı düşünüyordum. Kayıt zamanı geçmişti ama gecikmeli de olsa dekana gittim. Bir şans eseri dekanın odasında bulunduğum sırada o büyük âlim de odaya girdi. İri yarı bir adamdi. Durdu. Dekanla konuşmamın bitmesini bekledi. Dekan ona Ritter Bey dedi. Sizin talebeniz olma başvurusunda bulunan bir insanla konuşuyorum dedi. Hoca bana şöyle bir bakt1, Galiba bu benim dünkü seminerimdeydi dedi. (...) Bana biraz konuşalım dedi. Çok zor bir şeye talipsiniz. Arapça öğrenmelisiniz. Bende zor hocayım. Benim talebelerim benden hep kaçar, biliyor musunuz? dedi. Biliyorum, bana bunları anlattılar. Ben bunlara rağmen bu tehlikeye girmek istiyorum dedim. Güldü, peki dedi. Böylece onun talebesi oldum" (Sezgin, 2014: 13-14).

1943 yılında İstanbul Üniversitesi Şarkiyat Araştırmaları Enstitüsü'ne kaydını yaptıran Sezgin, yükseköğretim tercihini İslam bilimler tarihi (doğubilim) alanında yapmıştır (Ekici, 2013: 391). Şarkiyat Araştırmaları Enstitüsü’nde İslam bilimler tarihi alanına yönelmesiyle ilgili düşüncelerini Sezgin, şu sözlerle ifade etmiştir:

"O enstitüyü dünyanın en ünlü oryantalistlerinden Hellmut Ritter idare ediyordu. Daha ilk aylarda bir gün seminerinde İslam atomizminden bahsediyordu. Parmak kaldırdım, sordum. İslam'da önemli bir matematik var mıydı? Hayretle bana baktı. Cevabı şuydu: İslam dünyasında çok sayıda, Yunanlılarda ve modern 
çağlarda Avrupa'da tanıdığımız en büyük adlar kadar büyük matematikçiler yetişmiştir. Misal olarak birkaç ad saydı. Bu cevap beni dehşete düşürmüş, uykusuz bir gece yaşatmıştı. $O$ günden itibaren, artan bir açıklıkla Müslümanların bilimler tarihine olan katkısını hiç bilmeyen bir dünyada 17. yüzyıldan itibaren sayıları gittikçe artan bazı Avrupalıların, gerekli dilleri öğrenerek Arapça, Farsça ve Türkçe kitapların tercüme, yayım ve etüdüne başladıklarını, bunların birçoğunun İslam dünyasının genel bilimler tarihine önemli veya çok önemli bir katkısı olduğu gerçeğini savunduklarını öğrendim. Çok genç yaşımda yapılanları öğrenmeye, mümkünse olanlara bir katkıda bulunmaya karar verdim" (Sezgin, 2011: 90). ettirmiştir:

Sezgin, bu hususla ilgili düşüncelerini yapmış olduğu bir röportajında şu sözlerle devam

“Benim öğrenciliğim döneminde İstanbul Üniversitesi’nde bilim tarihi yoktu. Ancak, hocam bana matematiği bırakma dedi. Fen Fakültesi yanımızdaydı. Matematik bölümüne git, matematiği iyi öğren. Çünkü Müslümanlardan büyük matematikçiler yetişmişti biçiminde izahatta bulundu. Konuşma esnasında birkaç isim saydı. Harezmî, Ebu'l-Vefa Buzcanî, İbn Heysem, Biruni gibi. Bu isimler benim hiç bilmediğim hatta duymadığım isimlerdi. Dehşete düştüm. Hocam, bunlar ve daha pek çok isim büyük âlimlerdi ve daha sonraki Avrupalı âlimlerle aynı seviyedeydiler. Hatta yer yer onlardan da üstündüler diye açıkladı. Bu konuşmadan sonra da bilim tarihi yapmaya karar verdim" (Fazlığlu, 2004: 356).

İkinci dünya savaşının ilerleyen yıllarında Alman ordusunun Bulgaristan üzerine ilerlemeyesiyle dönemin hükümeti tarafında tüm Türkiye'deki üniversite öğrenimine kısa süreliğine ara verilmiştir. Ritter, bu süreç içerisinde öğrencilerine Arapça öğrenmeleri hususunda öneride bulunmuştur. Hocasının bu önerisi doğrultusunda yoğun olarak Arapça öğrenmeye başlayan Sezgin, Muhammed bin Cerir Taberi'nin tefsiri üzerinde alt1 ay boyunca ciddi bir biçimde çalışarak Arapçasını ilerletmiştir. Sezgin, bu çalışma süreci sonunda Ebu Hamid elGazali’nin ‘'̇hya-u Ulûm'id-din' isimli eserini kolayca okuyacak seviyeye ulaşmışıtır (Sezgin, 2016: 23). Sezgin, Arapça eserleri okumaya başlamasıyla hocası Ritter'in kendisiyle övünç duyması hususunda şöyle bir açılamada bulunmuştur:

"Benim hocam, çok meşhurdu. Seminerleri vardı. Alman profesörler de gelirdi. Yahudiler de vardı. Hürmet ederlerdi hocama. $\mathrm{O}$, beni göstermek istedi onlara. Gazali'nin 'İhya-u Ulûm'id-din' kitabını önüme koydu. Ben gazete okur gibi okudum. Belki hayatımda hocayı o kadar mesut görmemiştim. Talebesinin başarısı onu çok sevindirdi. Diğer Alman Yahudi profesörlere ben hayatımda bir dili bu kadar kısa sürede öğrenen insana rastlamadım dedi” (Sezgin, 2016: 9).

1947 yılında Bedi ilminin gelişimi hususundaki lisans bitirme tezini hazırlayan Sezgin, Ritter danışmanlığında İbn el-Musenna'nın 'Mecâz'ul-Kur'an'ındaki filolojik tefsiri ile ilgili tez hazırlamıştır. 1956 yılında Ritter'in danışmanlığında 'Buhari'nin Kaynakları Hakkında Araştırmalar' adında doktora tezini hazırlayarak doktor unvanını kazanmıştır (Schoeler, 1997: 423). Doktora tezi çalışmaları sırasında Mecâz'ul-Kur'an'ın çeşitli kısımlarında el-Buhari'nin hadis eserinden yararlanıldığ 1 tespit eden Sezgin, bu tespitiyle önceki akademisyenlerin ve muhaddislerin eserlerinin yalnızca sözlü geleneğe dayandığına ilişkin açıklamaların doğru olmadığını kanıtlamıştır (Sezgin, Ekim 2016: 23-24). Buradan anlaşılacağı üzere Sezgin, doktora çalışmasında Buhari'nin (810-870) kendinden önceki yazılı literatürden yararlanma imkânı bulamadığ i için İslam coğrafyasının çeşitli bölgelerine giderek hadis ravileriyle görüşmek yoluyla elde ettiği sözlü bilgilerden eserlerini hazırladığına dair (Sezgin, 1956: V-VI) hem Batı dünyasında hem de İslam dünyasında genel kabul gören kanaati yanlışlamaya çalışmıştır (Sezgin, 2014: 37). Başka bir ifadeyle Sezgin, 'Buhari'nin Kaynakları Hakkında Araştırmalar' isimli eserinde hadis rivayetlerinin uzun bir dönem yalnızca ezberden olduğu düşüncesini eleştirmekte 
ve 'Sahih-i Buhari’ temelinde ilgili görüşün yanlışlığını kanıtlamaya çalışmaktadır (Albayrak, 2016: 51). Dolaysıyla Sezgin, yapmış olduğu çalışmasında Buhari’nin hadis eserlerinin sözlü ifadeleri değil, yazılı metinleri referans aldığını ve yazılı metinlerin İslam'ın eski dönmelerine kadar gittiğini kanıtlamaya çalışmıştır.

27 Mayıs 1960 tarihinde meydana gelen askeri darbenin arifesinde dönemin hükümeti tarafından hazırlanan yasa ile yüz kırk yedi akademisyen ülkenin farklı üniversitelerinden uzaklaştırılmıştır. İstanbul Üniversitesi’nden uzaklaştırılan hocalar arasında Fuat Sezgin hocanın ismi de bulunmaktadır. Sezgin, yaşanan bu olumsuz durumla ilgili olarak düşüncelerini şöyle açıklamıştır:

"1960 yıllnda bir hükümet darbesi oldu. Askerler devletin idaresini ele geçirdiler. Millî Eğitim Komitesi adında bir komite kurdular. Bir gün bunlar 'Hangi profesörler zararlıdır?' diye bir liste çıkarmışlar. Bunların listeleri kanun gibidir. Gazeteler, 147 profesörün atıldığını yazıyordu. Benim de adım vardı. Askeri idarenin, bir mülki idareyi bertaraf ederek devletin başına geçmiş olmasından memnun olmadım. Birçok şeyler bekliyordum, ama bir gün üniversiteden atılacağımı beklemiyordum. Hatta Türkiye'yi kendiliğimden terk etmeyi de düşünmüyordum. Çünkü memleketime çok bağlıydım. Bu hadiseden bir yıl evvel, Almanya'da misafir doçent olarak bulunuyordum. Bana orada, doçentlik yapmamı teklif ettiler. Bu teklifi gülerek reddettim. Ben İstanbul'u, Türkiye'yi nası1 terk ederim? dedim. Özür dilediler. Gazetedeki zararlı profesörler listesini ve ismimin bu listede olduğunu görünce ülkeden gitmemin artık benim iradem dışında olduğunu anladım" (Aras, 2008: 1).

1960 yılında İstanbul Üniversitesi’nde doçentlik kadrosunda öğretim görevlisiyken üniversitedeki görevine son verilen Sezgin (Kenan, 2003: 79), 1961 yılında Almanya'ya giderek Frankfurt Üniversitesi Bilimler Tarihi Enstitüsü’nde misafir öğretim üyesi olarak dersler vermeye başlamıştır (Sezgin, 2014: 19-20). Frankfurt Üniversitesi'nde göreve başlayan Sezgin, yaşamak ve çalışmak için Almanya'yı seçme sebebi hususunda şunları söylemiştir:

“1960’ın sonlarına doğruydu, bir gün evimden dişarıya çıtım. Baktım gazete satan çocuklar bağırıyorlar. Yazıyor, yazıyor, 147 profesörün üniversiteden atıldığını yazıyor diye. Bende enstitüye gidiyordum. Gazeteyi aldım, baktım, benimde adım yazılıydı. Gazeteyi alıp çantama koydum. Enstitüye değil, Süleymaniye Kütüphanesine gittim. Kitap okumaya başladım. (...) Memleketimi çok seviyordum. Çok şeyler yapmak istiyordum. Bir enstitü kurmuştum. Saat gibi işliyordu. Tamamıyla Avrupa'da öğrendiğim her şeyi oraya getirmiştim. (...) Süleymaniye Kütüphanesi'ne gittim. Amerika'daki, Almanya'daki dostlarıma birkaç kısa mektup yazdım. Bugünden itibaren ben üniversiteden atılmış bir insanım, yanınızda çalışmak isterim, benim için bir yer var mıdır? diye. Aşağı yukarı 10-15 gün içerisinde üç üniversiteden cevap geldi. Frankfurt Üniversitesi, Berkeley Üniversitesi ve Yale Üniversitesi. Düşündüm, taşındım. Daha kitabımın (İslam Bilim Tarihi) bütün malzemelerini toplama işim bitmemişti. İstanbul'dan uzaklaşmak istemiyordum. Doğu'dan, yani Mısır'dan, İran'dan uzaklaşmak istemiyordum. Çünkü daha toplamam gereken bir sürü malzeme vardı. Frankfurt'ta karar kıldım. Çünkü dünyanın tek bilimler tarihi enstitüsü oradaydı. (...) Yavaş yavaş işlerimi bitirip oraya gittim" (Sezgin, 2014: 63-64).

1961 yılında Frankfurt Üniversitesi'nde çalışmaya başlayan Sezgin, sonrasında Almanya'da kalacak ve tüm çalışmalarını Almanya'da tamamlayacaktır (Ekici, 2013: 392). 1961 tarihinde Almanya'ya göç eden Sezgin, Frankfurt Üniversitesi'nde Bilimler Tarihi Enstitüsü’nde (Institut für Geschichte der Naturwissenschaften) başlangıçta misafir öğretim üyesi olarak dersler vermiştir (Sezgin, 2015b: 1). 1965 tarihinde Frankfurt Üniversitesi Bilim Tarihi Enstitüsü’nde İslam kimyacısı Cabir İbn Hayyan hakkında ikinci habilitasyon çalışmasını yapan Sezgin (Sezgin, 
Ekim 2016: 24), aynı y1l Frankfurt Üniversitesi’nde profesörlük unvanı almıștır. Frankfurt Üniversitesi'nde ki bilimsel çalışmalarını Arap-İslam Edebiyat Tarihi alanında (Geschichte des Arabischen Schrifttums) sürdürmüştür (Mahsereci, 2018). İslam bilim ve teknoloji tarihi alanındaki çalışmalara tüm yaşamını adayan Sezgin, ulusal ve uluslararası alanda yaptığı bilimsel faaliyetler ile birçok ödüle ve nişana hak kazanmıştır. Bunlar arasında Kahire Arap Dili Akademisi, Şam Arap Dili Akademisi, Fas Rabat Kraliyet Akademisi, Bağdat Arap Dili Akademisi, Türkiye Bilimler Akademisi şeref üyeliğidir. Bununla birlikte Erzurum Atatürk Üniversitesi'nde, Isparta Süleyman Demirel Üniversitesi'nde, İstanbul Üniversitesi'nde ve Kayseri Erciyes Üniversitesi'nde Sezgin'e fahri doktora takdim edilmiştir. Bununla birlikte Kral Faysal Ödülü (1978), Frankfurt am Main Goethe Plaketi (1980), Almanya Birinci Derece Federal Hizmet Madalyası (1982), Almanya Üstün Hizmet Madalyası (2001), İran İslami Bilimler Kitap Ödülü (2004), Hessen Kültür Ödülü (2009), T.C. Cumhurbaşkanlığı Kültür ve Sanat Büyük Ödülü (2013) ve Kültür-Turizm Bakanlığ Özel Ödülü (2016) sahibi olmuştur (Sezgin, Ekim 2016: 26).

Sezgin, İslam bilim ve teknoloji tarihi alanındaki çalışmaları yanında çeşitli kurumların kuruluşunu sağlamış ve birçoğunun kuruluşuna da öncülük etmiş̧ir. 1982 tarihinde Frankfurt Goethe Üniversitesi'nde Arap-İslam Bilimler Tarihi Enstitüsü'nü 'Institut für Geschichte der Arabisch-Islamischen Wissenschaften' (Sezgin, 2008: 15), 1983 tarihinde Frankfurt'ta Arapİslam Bilimler Tarihi Enstitüsü Müzesi'ni, 2008 tarihinde İstanbul İslam Bilim ve Teknoloji Tarihi Müzesi'ni kurmuştur. Ayrıca 2010 tarihinde Prof. Dr. Fuat Sezgin İslam Bilim Tarihi Araştırmaları Vakfı'nın kuruluşuna, 2013 tarihinde Fatih Sultan Mehmet Vakıf Üniversitesi Bilim Tarihi bölümünün kuruluşuna, 2013 tarihinde FSMVÜ Prof. Dr. Fuat Sezgin İslam Bilim Tarihi Enstitüsü'nün kuruluşuna ve 2015 y1lında Prof. Dr. Fuat Sezgin İslam Bilim Tarihi Araştırmaları Vakfı Yayınevi'nin kuruluşuna öncülük etmiştir (IBTAV, 2019).

İslam medeniyeti tarihi üzerinde çalışmalar yürütmüş, eserler vermiş ve birçok öğrenci yetiştirmiş olan Sezgin, 30 Haziran 2018 tarihinde İstanbul'da hayata gözlerini kapatmıştır.

\section{Eserleri}

Tüm yaşamını bilime adayan Sezgin'in; yazdığı, tercüme ettiği veya editörlüğünü yaptığı birçok eseri bulunmaktadır (Karakaş, 2015: 93). İslâm bilim tarihinde tarih, felsefe, coğrafya, tıp, matematik, geometri, astronomi, fizik, kimya, optik, mimari ve tabiat ilimleri gibi bilimin hemen hemen tüm alanlarında ki çalışmaların tanıtımını hazırlayıp çoğunu tasnif ve tahlil, edisyon kritik, tercüme ve tıpkıbasım yöntemleriyle bilim dünyasına kazandırmıştır (Kenan, 2003: 76). Sezgin bu eserlerde “...Kur'an ve hadis ilimleri, tarih, fikih, kelam, tasavvuf, şiir, tıp, farmakoloji, zooloji, veterinerlik, simya, kimya, botanik, ziraat, matematik, astronomi, astroloji, meteoroloji, tarih, dil bilgisi, matematiksel coğrafya, İslam'da kartografya (haritactlık) ve İslam felsefe tarihi gibi konular üzerine çalışmalar yapmıştır" (İdin, 2018).

Sezgin'in temel bilimler, sosyal bilimler ve formel bilimler alanında yapmış olduğu çalışmaların amacı, İslam medeniyetinin bilimler tarihindeki yerinin ve İslam âlimlerinin bilimler tarihindeki yaklaşık sekiz yüz yıllık yaratıcı devirlerinin dünya tarafından tanınmasını sağlamaktır (Ekici, 2013: 396).

Sezgin, bilimler tarihinde ilk olarak Ritter'in yönlendirmesiyle Alman oryantalist Karl Brockelmann'ın temel eser olarak kullanılan beş ciltlik Arap Edebiyat/Kültür Tarihi 'Geschichte der Arabischen Litteratur' (GAL) isimli eserinin tashihi üzerinde çalışmaya başlamıştır. Sezgin'in Brockelmann'ın Arap Edebiyatı Tarihi isimli eseri üzerine çalışması ilerledikçe kitapta birçok açıdan eksikliler oluğunu tespit etmiştir. Böylece eserin tashihten ziyade yeniden yazılması gerektiğine karar vermiştir (Sezgin, 2014: 69-70). Eserinin yeniden yazılması konusunda farklı gerekçelere sahip olan Sezgin, ilk olarak eserin objektif bir bilim tarihi perspektifinden yazılmadığını ileri sürmüştür. Bu hususla ilgili olarak Sezgin, şu açıklamada bulunmuştur: "Brockelmann'a birçok yönden şükran duyuyorum. Fakat bu adamcağız, İslâm dünyasını sevmiyordu. Kitabında maalesef hiçbir müspet hüküm yoktur. Başka oryantalistlerin menfi 
hükümleri vardır. (...) Ayrıca eseri de bibliyografik bir kitaptır" (Karakaş, 2015: 93). Eseri yeniden yazılması hususundaki bir diğer gerekçesi ise eserde El-Biruni, el-Kindi, Farabi, İbn-i Sina vb. birçok İslam düşünürünün temel bir konu olarak değil de yan bir konu olarak ele alınmasıdır (Ekici, 2013: 394). Bunun üzerine Sezgin, Brockelmann'ın eserindeki eksiklikleri tamamlamak için kapsamlı bir zeyil (eklenti) yazmayı düşünmüştür. Fakat eser üzerine bir süre çalıştıktan sonra eserde birçok eksikliklerin olduğunu tespit eden Sezgin, zeyil yazmaktan vazgeçerek özgün bir eser yazmaya karar veriştir (Karakaş, 2015: 93-94). Sezgin, Ritter'e eserin eksikliklerini tamamlamaktan ziyade tekrardan yazacağını söylemiştir. Ritter, onun bu kararı ile ilgili olarak şunları ifade etmiştir: "Yazamazsınız, bunu hiç kimse yapamaz. Zor, bu işe girmeyiniz, mütevazı olunuz" (Sezgin, 2014: 69-70). Sezgin, hocası Ritter' in tüm uyarılarına karşın yeni bir eser yazımına girişmiştir

Arap Edebiyat Tarihi'nin 'Geschichte der Arabischen Litteratur' (GAL) en önemli çalışması olarak kabul edilen esere zeyl yazmaktan vazgeçen Sezgin, Arap-İslam Bilim Tarihi isimli eserini 'Geschichte des Arabischen Schrifttums' (GAS) yazmaya başlamışıtır. Sezgin, eserin ön çalışması sürecinde başta İslam ülkeleri olmaz üzere birçok ülkenin kütüphanesinde binlerce cilt yazma eserler üzerinde araştırmalar yapmıştır (Ekici, 2013: 394). 7. yüzy1l ile 14. yüzyıl arasındaki dönemi kapsayan Arap-İslam Bilim Tarihi araştırmalarına İstanbul'da başlayan Sezgin, bu alandaki faaliyetlerine Almanya' da da devam etmiştir. Arap-İslam Bilim Tarihi isimli eserin ilk cildini 1967 tarihinde (Mahsereci, 2018) son cildini 2015 tarihinde yayımlanmıştır. Yaklaşık yarım asırlık bir sürede hazırlanan eserin tamamı on yedi cilt ve sekiz bin sekiz yüz yirmi sayfadan oluşmaktadır. Eserin I. cildi 1967 tarihinde yayınlanmış olup kıraat, Kur'an ilimleri, hadis, tarih, fikıh, kelam, tasavvuf konularını; II. cildi edebiyat, şiir konularını; III. cildi tıp, eczacılık, zooloji, veterinerlik konularını; IV. cildi simya, kimya, botanik, ziraat konularını; V. cildi matematik konularını; VI. cildi Astronomi konularını; VII. cildi astroloji, meteoroloji konularını; VIII. cildi sözlük çalışmalarını; IX. cildi gramer konularını; X. XI. XII. cildi matematiksel coğrafya ve haritacılık konularını; XIII. cildi matematiksel coğrafya ve haritacılık konularını; XIV. XV. cildi beşeri coğrafya konularını; XVI. cildi 2015 tarihinde yayınlanmış olup retorik, şiir, antolojiler, edebî teori ve edebî nesir konularını; XVII. cildi 2015 tarihinde yayınlanmış olup eğitim ve eğlence konularını ele almaktadır (Hansu, 2016: 222-223). Sezgin, on yedi ciltlik eserinin ilk cildini tefsir, hadis, kelam, fikıh, tasavvuf gibi temel İslam ilimlerinin tanıtımına tahsis etmiş, geri kalan ciltlerin tamamında Müslüman bilginlerin tarih boyunca bilim ve teknik alanındaki katkılarını incelemiştir. Sezgin, kısaca GAS olarak adlandırılan Arap-İslam Bilim Tarihi isimli eserindeki tezlerini hem İslam kaynaklarına hem de Batılı kaynaklara dayandırmıştır (Hansu, 2016: 225).

Sezgin'in on yedi ciltten oluşan Arap-İslam Bilim Tarihi 'Geschichte des Arabischen Schrifttums' (GAS) isimli kitabı Brockelmann'ın beş ciltlik Arap Edebiyat/Kültür Tarihi 'Geschichte der Arabischen Litteratur' (GAL) isimli eserinin sistematiği çerçevesinde hazırlanmış özgün bir eserdir. Sezgin, oryantalistik araştırmalar için kaynak esere dönüşen bu çalışmasıyla 1982 tarihinde İslâm dünyasının önemli ödüllerinden birisi olan 'Kral Faysal Ödülü’ nü almıştır (Kenan, 2003: 76). Bununla birlikte Alman ve Fransız oryantalist araştırmacılar Brockelmann'ın kitabının yeni baştan yazımının bir kişi tarafından değil, bir komisyon tarafından yapılması gerektiğini belirtmiştir (Sezgin, 2015a: IX). Komisyon üyeleri redaksiyon işi konusunda “(...) biz bunu bir Türk'ün veya bir Müslüman'ın yapabileceğine inanmıyoruz" (Sezgin, 2014: 72-73) şeklinde açıklama yapmışlardır. Sezgin Arap-İslam Bilim Tarihi 'Geschichte des Arabischen Schrifttums' (GAS) isimli eserin birinci cildi 1967'de yayımlandığında oryantalist araştırmacıların kanaatlerinin olumlu olarak değiştiğini ifade etmiştir (Sezgin, 2014: 72-73). Ayrıca eserin ilk cildini değerlendirmesi için hocası Ritter'e gönderen Sezgin, onun böyle bir çalışmayı bu güne kadar kimsenin yapmadığını belirtmesiyle hocasının takdirini kazanmıştır (Sezgin, Ekim 2016: 25). Dolayısıyla Sezgin'in nerdeyse tüm yaşamını adamış olduğu eseri hem doğu dünyası hem de Batı dünyası araştırmacıları tarafindan kaynak eser olarak kabul görmüştür. 
Diğer yandan Sezgin, dünyanın değişik coğrafyalarında ve dönemlerde yaşayan İslâm âlimlerinin muhafaza edilemeyen veya yalnızca eserlerde teorik bir biçimde anlatılan veya çizimleri var olan icatlarını yeniden aletleştirmiştir. Ayrıca Osmanlı İmparatorluğu döneminde yaşamış bilginlerinin eserlerinin de olduğu sekiz yüzden fazla mekanik araç yapmıştır. $\mathrm{Bu}$ mekanik araçlar, Almanya'da Johann Wolfgang Goethe Üniversitesi'nin Arap-İslam Bilimleri Tarihi Enstitüsünde kurulan müzede sergilenmektedir (Kenan, 2003: 77). Bununla birlikte tıbbi olsun, coğrafi olsun, astronomik olsun, matematik ile ilgili olsun bugün örneği bulunmayan bilimsel aletler hakkında elyazmalarını inceleyerek, bunların tasvirlerini çıkartarak aletlerin birebir replikalarını yapmıştır (Şengör, 2004: 13). Görüldüğü üzere Sezgin, eserlerinin yansıra İslam dünyasındaki bilginlerin sadece torik düzlemde kalan çalışmalarını da pratiğe dökerek yeniden gün yüzüne çıkarmıştır.

Sezgin yarım asırlık çalışmaları neticesinde başta İslam Bilim Tarihi 'Geschichte des Arabischen Schrifttums' (GAS) olmak üzere birçok eser meydana getirmiştir. Bu eserlerinde tefsir, hadis, fikıh, kelam gibi temel İslam ilimlerinin yansıra astronomi, astroloji, meteoroloji, coğrafya, matematik, tıp, farmakoloji, fizik, kimya ve felsefe gibi farklı bilimlerin tarihsel sürecini incelemiştir. Sezgin, dünya çapında kabul gören eserleriyle adeta yok sayılan İslam medeniyetinin varlığını yeniden ortaya çıkarmıştır. Böylece İslam dünyasının bilim ve teknoloji alanında önemli çalışmalar yapan bir medeniyet olduğunu güçlü bir biçimde dünyaya duyurmuştur.

\section{3. Şahsiyeti ve Değerleri}

İslam bilim ve teknoloji tarihi alanında yapmış olduğu çalışmaları ile İslam medeniyetinin bilimler tarihine katkılarını objektif bir biçimde ortaya koyan Sezgin, tüm bu çalışmalarını yüksek bir çalışma disiplini ve isteği içerisinde gerçekleştirmiştir. İslam bilimler tarihi alanındaki tüm eserlerini yoğun bir çalışma temposunda gerçekleştiren Sezgin, çalışma disiplininin ve isteğinin, mücadeleci tavrının üniversite yıllarından başladığını belirtmiştir.

İstanbul Üniversitesi'nde Alman oryantalist Ritter'in öğrencisi olan Sezgin, hocasının eğitim sürecindeki tüm taleplerini yerine getirmiştir. Sezgin'deki çalışma disiplinini fark eden Ritter, öğrencisinin daha nitelikli yetişmesi için onu üniversitenin ilk sınıfinda başta Latince ve Yunanca olmak üzere Farsça ve Arapça öğrenmeye yönlendirmiş̧tir (Sezgin, Mayıs 2016: 8). Hocasının isteği ile yabancı dilleri öğrenmeye başlayan Sezgin, Arapça'da hocasının istediği seviyeye gelememiştir. Bu durumu kendisine dert edinen Sezgin, bu hususla ilgili olarak şöyle bir açıklama yapmıştır:

\footnotetext{
“Arapça öğrenmeye başlamıştım. Ama hiçbir mesafe kaydetmiyordum. Bütün gayretlerime rağmen hocam ilk aylarda benden memnun değildi. 1943 yilında Almanlar, Bulgaristan'a girmişlerdi. Bizim hükümet, bütün üniversiteleri, mektepleri tatil etti. Hocam bana dedi ki: Şimdi elinizde bir firsat var. Altı aylık bir tatiliniz olacak. Bu zaman içeresinde Arapçayı öğrenin. Fakat bu söz bana çok tesir etti. Hakikaten altı ay kendimi Arapça öğrenmeye verdim. Evimizde babamdan kalma otuz ciltlik Taberi tefsiri vardı. Onu okumaya başladım. Başlangıçta anlamıyordum. Türkçe tefsirlerle karşılaştırarak yavaş yavaş tefsirin içine girmeye çalıştım. Günde aşağı yukarı on yedi saat çalışıyordum. Erken kalkıyordum, gece geç yatıyordum. Evden hemen hemen hiç çıkmıyordum. Altı ay sonra Taberi tefsirinin otuz cildini bitirmiş oldum. Başlangıçta hemen hemen hiç anlayamadığım bu tefsiri altı ayın sonunda gazete gibi okuyordum.(...) Hocama gittim. İlk ders seminerinde bazı Alman profesörler vardı. Hocam önüme Gazali'nin İhyâ'ü Ulûmiddîn adlı eserini koydu. Okuyun bakalım dedi. Okudum.(...) Hocam bana bakt1, gülümsedi, sevindi. Orada beni biraz methetti. Benim için o an hayatımın unutulmaz anıydı. Arapça'da artık kitapları okuyabilecek hale gelmiştim" (Sezgin, 2014: 15-16).
} 
Buradan da anlaşılacağı üzere İkinci Dünya Savaşı sırasında Alman silahlı kuvvetlerinin Bulgaristan'a hareket etmesi sebebiyle Türkiye'de üniversite öğretimine altı ay süreyle ara verilmiştir. Ritter, bu arada öğrencilerine Arapça öğrenmelerini tavsiye etmiştir. Bu süreçte Muhammed bin Cerir Taberi'nin tefsirini okumaya karar veren Sezgin, eski dille yazılan tefsiri kavrayabilmek adına altı ay süresinde günlük on beş saatten fazla çalışmıştır. Bu süreç sonunda Taberi tefsirinin Arapça çözümlemesini yaparak Arapçasını önemli ölçüde geliştirmiştir (Sezgin, Mayıs 2016: 8-9). Bu noktada çalışma disiplinine verdiği önemle ilgili olarak Sezgin, şunları söylemiştir:

Bir hoca vardı. Hem de büyük bir hoca.(...) Alman asıllı Helmutt Ritter.(...) Bir süre konuştuktan sonra içimden büyük bir adammış dedim.(...) $\mathrm{O}$ an karar verdim. Şarkiyat okuyacağım. Ritter ile çalışmaya başladım.(...) Çalışmaya başladıktan bir iki gün sonra bana 'Fuat, günde kaç saat çalışıyorsun?' diye sordu. On üç on dört saat çalışıyorum dedim. O zaman bana 'Bu çalışmayla âlim olamazsın. Eğer âlim olmak istiyorsan daha çok çalışacaksın. Benim hocam Eilhard Wiedemann günde yirmi dört saat çalışırdı. Gün daha uzun olsaydı daha çok çalışırdı dedi.’ Ben bu konuşmadan sonra çalışma saatlerimi yavaş yavaş artırdım. On yedi saate kadar çıkardım. Uzun zaman böyle devam ettim (Fazlioğlu, 2004: 355).

Sezgin, bilim hayatında merakın ve çalışma disiplininin önemi ile ilgili sözlerine şu şekilde devam etmiştir:

"Hocamla kütüphanelere gidiyorduk ve yazmaları tarıyorduk. İstanbul'da o zaman iki yüz binden fazla yazma eser vardı. Onların hemen hemen hepsini görmek lazımdı. Ne yapıyordum? Kütüphanelerin muayyen temizlik günleri vardı. Temizlik günlerini ben kaydederdim. Kütüphanecilere lütfen başladığınız zaman bana haber verin, ben de gelip o yazmaları görmek istiyorum. Bu bir firsattı benim için. Onlar birden başlayıp iki bin, üç bin ciltlik kütüphaneyi temizliyorlardı. Ben de onların eline geçen her yazmayı elime alıyordum. Yazmalara bakıp çok mühimlerini kaydedip ondan sonra bir daha gidip o yazmaları görüyordum" (Sezgin, 2014: 71).

Akademik yaşamında disiplinli çalışmanın önemine inanan bir bilim insanı olan Sezgin, araştırmalarında kararlı bir tutum içerisinde olmuştur. Bu kararlı tutumu sayesinde İslam bilim ve teknoloji tarihi alanında kaynak olarak kabul edilen çok önemli eser meydana getirmiştir. Sezgin, çalışmalarındaki kararlı ve azimli tutumu ile ilgili olarak şunları ifade etmiştir:

"Hocam seminerlerinde ara sıra Brockelmann'ın kitabının birçok noksanı olduğunu ve bunların giderilmesi gerektiğini söylerdi. Birisinin artık hiç olmazsa İstanbul'daki yazmalara dayanarak bu boşlukları gidermesi lazım derdi.(...) Ben de içimden ben bunu yapacağım derdim. Bu fikir bende gittikçe yerleşti.(...) Üniversiteyi bitirip doktoramı yapar yapmaz Brockelmann'ın kitabının noksanlarını gidermeyi kafama koydum ve derhal başladım. Doçent olduktan sonra bu işe daha da yoğunlaştım. İş ilerledi. İlerleyince baktım ki, Brockelmann'ın kitabındaki boşluklar giderilebilecek gibi değil. Düşündüm. Brockelmann kitabım yeni baştan yazma fikrini geliştirmeye başladım. Epeyce mesafe kat ettiğim bir sırada, o zamanlar Ritter Almanya'dan dönmüştü. Hocama Brockelmann'ın kitabına bir zeyl yazmak değil, dünyadaki bütün yazmalara bakarak yeni bir kitap yazmak istiyorum dedim. Bana dedi ki, onu yapamazsınız. Bunu hiç kimse yapamaz. Ben içimden hocam bunu yapacağım dedim. 1967 yılında kitabımın birinci cildi çıktı" (Sezgin, 2014: 16-17). 

etmiştir:

Sezgin, çalışmalarındaki kararlı ve azimli tutumu ile ilgili sözlerine şu şekilde devam

"1967 yılında kitabın birinci cildi, İslam Bilim Tarihi (Geschichte des Arabischen Schrifttums) çıkar çıkmaz hocama gönderdim. Üç dört ay cevap gelmedi. Ben o zaman Almanya'daydım, o da Türkiye'de. Kendisine bir mektup yazdım. Ne oldu hocam? Size kitap gönderdim, henüz cevap alamadım dedim. O zaman Ne acele ediyorsun? Koca kitabı okumak lazım şeklinde bir cevap gönderdi. Daha sonra gönderdiği bir karta şimdiye kadar böylesini hiç kimse yapamadı. Senden başka da hiç kimse yapamayacak. Tebrik ederim cümlelerini yazdı" (Fazlığlu, 2004: 359).

Görüldüğü üzere, İslam medeniyeti üzerine çalışmalarında her daim idealist bir bilim insanı kimliği ile hareket eden Sezgin, her zaman sistematik çalışma disiplini içerisinde olmuştur. İslam bilim ve teknoloji alanında yazdığ bırakmamıştır. Azmi, kararlılı̆̆ ve çalışma disiplini sayesinde kendi milletine, devletine, kültürüne ve medeniyetine önemli hizmetler yapmış inançlı bir şahsiyettir.

Öte yandan İstanbul Üniversitesi'nden ihraç edilen Sezgin, 1961 tarihinde Frankfurt Üniversitesi'nden çalışma davetiyesi almıştır. Frankfurt Üniversitesi'nde altı aylığına misafir öğretim üyesi olarak çalışırken üniversite yetkilileri tarafından kendisine iki aylık çalışma döneminin kaldığını söylenmiştir. Frankfurt Üniversitesi tarafından kendisine yapılan bu hatırlatma karşısında Sezgin, rektör yardımcısı Prof. Dr. Willy Hartner'e şöyle söylemiştir.

"Hiç üzülmeyin dedim. Ben hayatımı daima planladım. Liseyi şu zamanda bitireceğim diye planladım. Üniversiteyi öyle.(...) Şu yaşta doçent olacağım dedim. Bütün bunlarda muvaffak oldum. Baktım her şeyde muvaffak oluyorum, bende bir şımarma başladı. Ondan sonra bir askeri darbe geldi. Bir balığın üzerine atılan ăg gibi ben de $\mathrm{o}$ ağın içinde kaldım. O zaman baktım ki beşer olarak benim irademin bir sınırı varmış. İşte o olaydan sonra ben şuna karar verdim. Hayatımda eğer altı haftalık bir geleceğim garanti edilse, yani o kadar yaşayabilecek kadar maddi imkânım varsa yedinci haftayı düşünmeyeceğim. Onun için önümde iki ay daha var. Para da biriktirdim. Onları düşünmüyorum dedim.(...) Ayağa kalktı, beni kucakladı. Bana dedi ki: 'Ben ateistim, Allah'a inanmıyorum. Fakat bu kadar inanan bir insana ne kadar gipta ediyorum'(...) Sonra adam bana hissettirmeden çalışmış, kimlerle görüşmüş bilmiyorum. Orada Marburg şehri var bizden 100 km. ötede. Oradaki üniversitenin Hititler bölümü başkanı geldi. Bana dedi ki: 'Biz burada yeni Şarkiyat Kürsüsü kurduk, orada ders verecek kimse yok, siz bu dersleri üstünüze alır mısınız?' Ben de tamam dedim. Daha altı hafta dahi geçmeden oldu bütün bunlar. Böylece hayatımda çizdiğim yeni yolun doğru olduğuna inanmaya başladım" (Sezgin, 2014: 66).

İslam medeniyeti üzerinde yaptığı çalışmalarda merakı, çalışkanlığ 1 , disiplini, araştırma azim ve kararlılığ ile bilim tarihi alanında saygın bir konuma ulaşan Sezgin, özel yaşamındaki inançlı kişiliği ile bilim çevrelerinde saygınlık kazanmış bir bilim insanıdır. İslam bilim ve teknoloji alanında ki çalışmalarında hiçbir zaman bilim etiğini göz ardı etmediğini belirten Sezgin, her daim bilimsel faaliyetlerde dürüstlükten ödün vermediğini belirtmiştir. Sezgin bu hususla ilgili olarak Isparta Süleyman Demirel Üniversitesi’ndeki söyleşisinde şu açıklamada bulunmuştur:

"Elimden geldiği kadar çok çalışıyorum. Kitaplar keşfediyorum, onların da bulamadığı kitapları, ama hiçbir zaman kitabımda bilerek hata yapmadım. Hakikati hiçbir zaman bilerek zorlamadım. Arkamda bir takım hatalar bırakmaya çalışmadım. Bunu size garanti ederim. Bilime her zaman sadık kaldım” (Sezgin, Mayis 2016: 15). 
Görüldüğü üzere İslam medeniyeti üzerine ciddi çalışmalar yapmış olan Sezgin, bilimsel kimliği ile şahsiyetini bütünleştiren önemli bir insandır. Bilimsel çalışmalarında bilim etiğine sadık kalan Sezgin, kültürel kimliğini bilimsel araştırma sürecinde hiçbir zaman ön plana çıkarmamıştır. Sezgin, tüm eserlerinde ciddi çalışma faaliyeti içerisinde olmuş ve çalışma disiplinini hiçbir zaman bırakmamıştır. Azim ve kararlılığı ile birçok eser meydana getirmiş, inançlı bir insan olarak da dürüstlükten asla ödün vermemiştir. Bu bakımdan Sezgin, söylemleri ve eylemleri ile tutarlı olan erdemli bir bilim insanı olarak yaşamıştır.

\title{
4. Bilim Tarihi Paradigması
}

Sezgin açısından bilim tarihi, elde edilen araçların ve aletlerin tarihsel kayıtlarını tutmaktan öteye geçemeyen basit bir disiplin değildir. Bilim tarihi toplumsal yaşam içerisinde ki sosyal hayatın ve mantıksal düşüncenin de tarihidir. Sezgin'in bilim tarihi anlayışı hem bilim tarihi açısından hem sosyal tarih açısından bir sentez ortaya koymaktadır (Sezgin, 2004: 13). Demek oluyor ki bilim tarihi, insanlık tarihinde ki bilginin ortaya çıkması, gelişmesi ve değişmesi sürecinin detaylı bir anlatımı olarak ifade edilebilir.

Sezgin açısından bilim tarihinin konusu, tarih içerisinde ortaya çıkmış medeniyetlerin bilim tarihlerinin tespit edilmesi ve İslam bilim ve teknoloji tarihinin medeniyetler tarihindeki konumunun objektif bir biçimde tespit edilmesidir (Sezgin, 2012: 54-55). Bununla birlikte Sezgin açısından bilim tarihinin amacı, bilimlerin bugünkü yüksek düzeye ulaşmasında İslam kültür dünyasının rolünü objektif bir biçimde ortaya koymaktır (Sezgin, 2012: 55). Bu bağlamda Sezgin, İslam bilim ve teknoloji tarihi araştırmalarındaki amacı hususunda şu değerlendirmede bulunmuştur:

\begin{abstract}
"Ben bir kültür dünyasına mensubum. Bu kültür dünyasına yüzyıllardır zulüm edildiğini, hakkının yendiğini, asla lâyık olmadığı bir şekilde aşağılandığını gördüm. Bu kültür dünyasını, hakikaten olduğu gibi -ne eksik ne de fazladünyaya tanıtmayı kendime amaç edindim. Bu amacın bir bölümü dünya bilimine bir şey katmak fakat bir diğer bölümü koskoca bir insan topluluğuna kaybetmiş olduğu kendine saygıyı, kendine güveni, insan cemiyetindeki yerini hatırlatarak iade etmektir. Bunun için de çalıştım” (Sezgin, 2004: 11).
\end{abstract}

Dolayısıyla Sezgin'in bilim tarihi araştırmalarında ki genel amacının bilime hizmet etmek olduğu özel amacının ise İslam bilim tarihinin genel bilimler tarihindeki yerinin açıkça ortaya koyulması olduğu görülmektedir. Başka bir ifadeyle Sezgin'in bilim tarihindeki amacı, derin kültürel birikime sahip olan İslam medeniyetinin diğer kültürler karşısındaki köklü birikimini açığa çıkarmaktır. Böylece İslam dünyasının batı dünyası karşısında kaybettiği umudunu, özgüvenini ve yaratıcılığını yeniden kazanacaktır.

Sezgin açısından bilimler tarihi ardışık bir biçimde tarih sahnesine çıkan ulusların ve uygarlıkların etkileşimi neticesinde meydana gelmiştir. Antik Yunan biliminin kökeni Mısır ve Babil bilimine, İslam biliminin kökeni ise Yunan bilimine dayanmaktadır. Benzer bir biçimde Batı medeniyetinin elde ettiği bilimsel gelişmenin köklerinde İslam dünyasının izdüşümünü görmek mümkündür (Sezgin, 2004: 22). Başka bir ifadeyle İslam medeniyeti hem Yunan ve Helenistik bilim ve felsefe geleneğini sentezleyen İskenderiye'nin hem de Bizans, Pers, Asya, Çin ve Hint kültürlerinin mirasçısıdır (Bozkurt, 2004. 21). Aynı şekilde Batının 12'nci yüzyılla başlayan ve Rönesans'tan çağımıza uzanan bilimsel başarılarının İslam dünyasının bilimsel faaliyetlerine bağlılığı göz ardı edilemez (Yıldırım, 2012: 14). Bu bakımdan bilimler tarihinin tek bir ulusun veya uygarlığın eseri olmadığını belirten Sezgin'e göre bilim Mezopotamya'da doğmuş; oradan eski Yunan'a göç etmiş; eski Yunan'dan İslâm dünyasına gelmiş; oradan da tekrar Avrupa'ya dönmüş ve bu arada sürekli bir biçimde gelişmiştir (Sezgin, 2004: 13-14). Bilimler tarihinin bütünlük teşkil ettiğini düşünen Sezgin, bilim tarihçilerinin ödevinin ise bütünü oluşturan parçaları hakikate uygun bir biçimde, duygulardan ve ön kabullerden uzak nesnellik 
içerisinde tartışmak ve tanıtmak olduğunu belirtmiş̧tir (Sezgin, 2004: 22). Sezgin, bilimler tarihinin bir bütün olduğu hususunda şu açıklamayı yapmıştır:

"Ben altııs yıllık çalışma hayatım sırasında her gün biraz daha fazla İslam uygarlı̆̆ını tanımanın ve tanıtmanın Batı dünyasına ulaşma davası bakımından en sağlam daha doğrusu tek yolu olduğuna inandım. Bugünkü bilgime göre, genç Batı uygarlığını İslam uygarlı̆̆ının değişik coğrafî ve iktisadî şartlar altında gerçekleşen devamı olarak görüyorum. Bu anlamda İslam bilimleri Yunan bilimlerinin devamı olarak gelişti. Diğer taraftan Yunan bilimlerinin temelin eski Mısır ve Babilonya bilimlerine dayandığını bilimler tarihi ortaya koyuyor. Benim için bilimler tarihi bir bütündür" (Sezgin, 2012: 11-12).

Diğer yandan İslam'ın ilk yüzyılında bilimsel faaliyetler hususunda merak içerisinde ki İslam dünyası; Yunanca, Süryanice, Farsça ve Sanskritçe gibi dillerden başta astronomi, matematik, geometri ve coğrafya olmak üzere birçok alanlardan ilk çevirileri yapmıştır (Sezgin, 2004: 24-25). MS 9. yüzyılın başlarında Bağdat şehrinde Abbasi Halifesi Me'mun zamanında Beytï'l Hikme (Hikmet Evi-Hikmet Akademisi) adıyla bilim akademisi kurulmuştur. İslam dünyasının ilk bilim akademisi Beytü'l Hikme'de Müslüman, Hıristiyan ve Musevi dinlerine mensup bilginler yeni çeviriler yaparak, eski çevirileri düzelterek bilimin çeşitli alanlarında araştırmalar yapmışlardır (Sezgin, 2004: 26). Görüldüğü üzere Beytü'l-Hikme temel bilimler, sosyal bilimler ve formel bilimler alanındaki çalışmaların İslam dünyasında tanınmasında önemli rol oynamıştır (Sezgin, Şubat 2016: 26-27). Bu bakımdan İslam kültür dünyası MS 7. yüzyıldan itibaren başta eski Yunan eserlerinin çevirisiyle kazanılan birikim sürecinin ertesinde kendi yaratıcılığını geliştirmiştir. Böylece MS 16. yüzyıla kadar özgün bilimsel faaliyetler gerçekleştirmiştir. Bununla birlikte Sezgin açısından İslam medeniyeti sadece, Batı medeniyetinin eski Yunan dünyasının birikimlerini kazanmasında basit taşeronluk faaliyeti yapmamıştır. Bunun ötesinde, Batı dünyası 12. yüzyıldan itibaren İslam bilim dünyasının ürünü olan özgün eserlerle karşılaşmış, bu eserleri Latince'ye tercüme ederek kendi kültürlerine götürmüşlerdir (Sezgin, 2004: 7). Hatta İslam dünyası Yunanlılardan aldıkları bilimleri geniş ölçüde geliştirmiş ve yeni araştırmalar çerçevesinde yeni bilimler elde etmişlerdir (Sezgin, 2004: 33). Dolayısıyla İslam dünyası farklı ulus ve uygarlıkların bilimsel eserlerini kendi kültürlerine taşımışlar, bu eserler üzerinde çalışmışlar ve yeni problemler yaratmak şartıyla özgün eserler meydana getirmişlerdir.

Öte yandan 10. yüzyıldan itibaren Arapça eserler, Bizans'ta Yunanca'ya çevrilmeye başlamıştır. 11. yüzyılla birlikte Arapça eserler önce İbraniceye sonra da İbranice‘den Latinceye çevrilmiştir. 12. yüzyılda Fransa'nın ve İngiltere'nin birçok şehrinde çevrilen kitapların birebir replikaları yapılmaya başlanmıştır. Avrupa kültür tarihi 13. 14. 15. asırlarda bilginlerine önemli icatlar atfetmiştir. Sezgin açısından Avrupa'nın bu yüzyıllardaki bilimsel faaliyetleri tamamen kendi düşünürlerine bağlamaları onların İslam düşünürleriyle bağlarının göz önüne alınmadığının bir göstergesidir. Bununla birlikte Avrupa' da 17. yüzyıla kadar kaynak verme kavramı olmadığını belirten Sezgin, birçok Arapça eserin tercümesinin hem Avrupalı hem de Yunanlı bilginlerin adı altında yüzyıllarca yayınlandığını ifade etmiştir. Buna karşın Sezgin, yazılan veya çevrilen eserlerde kaynakların sistemli bir şekilde verilmesi ve önceki kuşakların emeklerinin anılması prensibinin İslam bilim dünyasının karakteristik niteliklerinden birisi olduğunu belirtmiştir (Sezgin, 2004: 34). Görüldügü üzere Avrupa'da yapılan bilimsel faaliyetlerde atıf verme veya kaynak gösterme alışkanlığının olmaması o dönemlerde bilim etiğinin yerleşmemiş olduğunun bir göstergesidir. $\mathrm{Bu}$ durumda birtakım bilimsel kazanımların Batı dünyasına atfedilesi olasılığının söz konusu olduğu söylenebilir.

17. yüzyıldan itibaren Batı dünyasının kendisini İslam dünyasından yüce görmeye başladığını belirten Sezgin, Avrupalıların bu durumu Rönesans (Renaissance; yeniden doğuş) kavramı ile açıkladığını ifade etmiştir. Bu kavram açısından Batıda 12. yüzyılla gelişmeye başlayan bilimsel ilerleme hamlesi doğrudan Yunan bilimlerinin Latince'ye tercümesine 
bağlanmıştır. Sezgin açısından bu düşünce çoğu bilim tarihçileri için tarihi hakikatlerle uyuşmamasına karşın, Batı dünyasında ve İslâm dünyasında genel kabul görmüştür (Sezgin, 2004: 20-21). Bunun anlamı 12. yüzyıldan itibaren İslam dünyasında ki bilimsel faaliyetlerde dekadans çağının başladığı kabulüdür. Bu kabule karşın İslam dünyasında 13. ve 14. yüzyılda bilimlerin birçok alanda yükseliş dönemi yaşadığını savunan Sezgin, Rönesans düşüncesiyle İslam dünyasının unutulmasını kabul etmemiştir (Sezgin, 2004: 34). Zira bu perspektif İslam kültür dünyasının bilim mirasının ihmal edildiği ve peşin hükümler çerçevesinde değerlendirildiği anlamına gelmektedir (Sezgin, Aralık 2014: 2). Bu bakımdan Batı dünyasının İslam dünyasına karşı bu tutumunun ideolojik histerilerden kaynaklandığını düşünen Sezgin, İslam dünyasına bilimsel geçmişinin güçlü olduğunu belirtmiştir. Bu hususla ilgili olarak Sezgin, şöyle bir değerlendirmede bulunmuştur:

Bütün geçmiş büyük uygarlıklarda olduğu gibi İslâm uygarlığı da politik, jeopolitik ve ekonomik koşullarla 16. yüzyıldan itibaren bir yıpranma çağı içine girmiştir. Uygarlık bayrağını taşıyacak ardılı kendisi geliştirmiştir. Şimdi o uygarlığın bugünkü ve yarınki kuşakları bu ardılın başarısı önünde aşağılık ve yabancılık duygusuna düşmeden ondan hızla öğrenmek, ona ulaşmak gereksinimi ile karşı karşıya bulunmaktadır (Sezgin, 2004: 34).

\section{Sonuç ve Öneriler}

Fuat Sezgin, İslam dünyasında bilim ve teknoloji alanında ki faaliyetlerin tespitinde ciddi çalışmalar yürütmüş önemli bilim insanlarından birisidir. İslam medeniyetinin binlerce y1llık kadim kültür dünyasının mirasını taşıdığını düşünen Sezgin, tüm yaşamını unutulmuş ve/veya unutturulmuş bu kültür mirasını ortaya çıkarmaya adamıştır. İdealist bir bilim insanı olan Sezgin, bilimsel hayatının çoğunu yurtdışında geçirmesine karşın kültürel kodlarını hiçbir zaman kaybetmemiştir. Yurtdışında geçen yarım asırlık süreç içerisinde Türk-İslam kültürünü her daim yaşamış ve yaşatmıştır. Yaşadığı tüm zorluklara karşın Türk-İslam kültürüne aidiyetini kaybetmemiştir. Türk-İslam kültürü ile hiçbir zaman çatışma yaşamamıştır. Her daim Türk-İslam kültürü ile barışık ilkeli bir yaşam sürmüştür.

Yurtdışında farklı kültürden gelen bir bilim insanı olarak kalmanın önemli ölçütlerinden birisinin kendi kimliğinde var olabilme olduğunu her zaman hatırlamıştır. Yabancı kültürler ve kimlikler karşısında kendi kültürünü ve milli kimliğini her zaman korumuştur. Kendi kültürü ve milli kimliği ile her daim onur duymuştur. Kendi kültürüne ve kimliğine aidiyetini açikça ortaya koymaktan geri durmamıştır. Bununla birlikte kökleri derinlere inmiş, dünya medeniyetine yön vermiş kadim bir kültürün ve milletin mensubu olmanın sorumluluğunu her zaman üzerinde taşımıştır. Müslüman bilim insanı olarak kültürüne, milletine ve insanlığa karşı sorumluluğunun yükünü hiçbir zaman hafife almayarak çalışmalarının titizlikle sürdürmüştür.

İslam medeniyeti üzerinde yaptığı bilimsel çalışmalarda hiçbir zaman çalışma azmini, kararlılığını ve disiplinini kaybetmemiştir. Türk-İslam kültürü üzerine yapmış olduğu çalışmalarını her daim daha ileriye taşımaya gayretinde olmuştur. Tüm yaşamını adamış olduğu çalışmalarında hiçbir zaman yorgunluk içinde olmamıştır. Her zaman vermiş olduğu kararların arkasında durarak çalışmalarında umutsuzluğa düşmemiştir. Bununla birlikte tüm çalışmalarını kendi milleti, kültürü, devleti ve medeniyeti adına ödev ahlakı içerisinde gerçekleştirmiştir. Bilimsel faaliyetlerinde hiçbir zaman objektivizmi bir kenara bırakmamış her zaman hakikatlerin peşinde olmuştur. Hakikat arayışında hem Batı kültürüne hem de İslam kültürüne karşı eşit mesafede objektif bir duruş sergileyerek doğruları hiçbir zaman çarpıtmamıştır. Böylece Sezgin, gerek Batı dünyasında gerekse İslam dünyasında yaygın yanlış kabulleri değiştirecek, medeniyetimize özgün perspektifler sağlayacak, kaybedilen özgüveni yeniden kazandıracak ve geleceğe umutla bakmamamıza imkân verecek bilimsel, kültürel ve değersel bir mirasın öncülerinden olmuştur. 


\section{Kaynakça}

Albayrak, A. (2016). Fuat Sezgin'in Buhari’nin Kaynakları Kitabı Üzerine Değerlendirmeler, Usul Íslam Araştırmaları, (26): 51-100.

Aras, H. (2008). Prof. Dr. Fuat Sezgin Kimdir? http://www.yaklasansaat.com/ dunyamiz/bilim_ve_teknoloji/fuat_sezgin_kimdir.asp (Erişim Tarihi: 09.04.2019).

Bozkurt, N. (2004). Bilimler Tarihi ve Felsefesi, İstanbul: Morpa Kültür Yayınları.

Ekici, A. (2013). Genç Hukukçular Hukuk Okumaları İçinde: Tarihi Uyanışın Mimarı: Prof. Dr. Fuat Sezgin (Ed: Muharrem Balc1). İstanbul: Matbaa Basım.

Fazlığlu. İ. (2004). Fuat Sezgin ile Bilim Tarihi Üzerine, Türkiye Araştırmaları Literatür Dergisi, 2(4): 355-370.

Germaner, S. İnankur, S. (1989). Oryantalizm ve Türkiye, İstanbul: Türk Kültürüne Hizmet Vakfi Sanat Yayınları.

Hansu, H. (2016). Fuat Sezgin: Arap-İslâm Bilimleri Tarihi I, İstanbul: Prof. Dr. Fuat Sezgin

İslam Bilim Tarihi Araştırmaları Vakfı Yayınları 2015, XIII + 1072 sayfa. İstanbul Üniversitesi Ilahiyat Fakültesi Dergisi (34): 221-228.

İdin, Ş. (2018). Prof. Dr. Fuat Sezgin Kimdir? http://bilimgenc.tubitak.gov.tr/makale/prof-drfuat-sezgin-kimdir (Erişim Tarihi: 07.04.2019).

İslam Bilim Tarihi Araştırmaları Vakfı (2019). Prof. Dr. Fuat Sezgin'in Öncülügündeki Kuruluşlar, http://www.ibtav.org/sayfa/2/onculugundeki-kuruluslar(Erişim Tarihi: 11. 04. 2019).

Karakaş. A. (2015). 20.Yüzyıl Hadis Eksenli Oksidentalizm Çalışmaları: Fuat Sezgin Örneği,Çukurova Üniversitesi Sosyal Bilimler Enstitüsü, Doktora Tezi, Adana.

Kenan, S. (2003). İslâm Dünyasının Duraklama Sebepleri Üzerine Ünlü Bilimler Tarihçisi Fuat Sezgin'i Dinlemek, Değerler Ĕ̈itimi Dergisi, 1(4): 73-98.

Mahsereci, N. (2008). Bilimin Merkezi Bir Zamanlar Doğu'daydıhttps://bilimvegelecek.com.tr/index.php/2008/02/01/prof-dr- (Erişim Tarihi: 08.04.2019).

Sezgin, F. (1956). Buhari'nin Kaynakları Hakkında Araştırmalar, İstanbul: İbrahim Horoz Basimevi.

Sezgin, F. (2008). İslam'da Bilim ve Teknik I, (Çev: Abdurrahman Aliy), İstanbul: İstanbul Büyükşehir Belediyesi Kültür A.Ş. Yayınları.

Sezgin, F. (2011). İslam'ın Bilimler Tarihindeki Yaratıcı Yerine Bir Bakış, Adam Akademi, 1: 89-98.

Sezgin, F. (2004). İslam Kültür Dünyasının Bilimler Tarihindeki Yeri, Ankara: Türkiye Bilimler Akademisi Formu.

Sezgin, F. (2012). İslam Bilimler Tarihi Üzerine Konferanslar İçinde: İslam Kültür Dünyasının Bilimler Tarihindeki Yeri (Ed: Zeynep Berktaş-Tuğçe İnceoğlu), İstanbul: Timaş Yayınları.

Sezgin, F. (2012). İslam Bilimler Tarihi Üzerine Konferanslar İçinde: Müslümanların Bilimler

Tarihinde 800 Yıl Süren Yaratıcı Merhalesini Ne Kadar Tanıyoruz (Ed: Zeynep Berktaş-Tuğçe İnceoğlu), İstanbul: Timaş Yayınları.

Sezgin, F. (2014). Bilim Tarihi Sohbetleri İçinde: İlmin Dar Kapısından Geçiş, Söyleşi Sefer Turan (Ed: Cüneyt Dalkıran), İstanbul: Timaş Yayınları. 
Sezgin, F. (2014). Bilim Tarihi Sohbetleri İçinde: İlk Eserler: İslam Bilim Tarihi, Söyleşi Sefer Turan, (Ed. Cüneyt Dalkıran), İstanbul: Timaş Yayınları.

Sezgin, F. (2014). Bilim Tarihi Sohbetleri İçinde: Battya Yolculuk, Söyleşi Sefer Turan (Ed: Cüneyt Dalkıran). İstanbul: Timaş Yayınları.

Sezgin, F. (2014). Bilim Tarihi Sohbetleri İçinde: Oryantalist Tezlere İtiraz ve Batı'daki Etkiler, Söyleşi Sefer Turan (Ed: Cüneyt Dalkıran) İstanbul: Timaş Yayınları.

Sezgin, F. (2014). Bilim Tarihi Sohbetleri İçinde: İstanbul'dan Ayrıllş Almanya'ya Gidiş, Söyleşi Sefer Turan (Ed: Cüneyt Dalkıran), İstanbul: Timaş Yayınları.

Sezgin, F. (2014). Bilim Tarihi Sohbetleri Iç̧inde: Bir Valizle Çıktım Yola. Söyleşi, Sefer Turan (Ed. Cüneyt Dalkıran), İstanbul: Timaş Yayınları.

Sezgin, F. (2014). Bilim Tarihi Sohbetleri İçinde: Eşim Benim İçin Çok Önemliydi, Söyleşi Sefer Turan (Ed: Cüneyt Dalkıran), İstanbul: Timaş Yayınları.

Sezgin, F. (2014). Bilim Tarihi Sohbetleri İçinde: Bu Kitabı Bir Türk Yazamaz, Söyleşi Sefer Turan (Ed. Cüneyt Dalkıran), İstanbul: Timaş Yayınları.

Sezgin, F. (Aralık 2014). 1984 Yılından 2011 Yılına Kadar Arap İslam Bilimleri Tarihi Enstitüsü Yayınlarına Yazılan Avrupa Dillerindeki Önsözler. İstanbul: Timaş Yayınları.

Sezgin, F. (2015a). Arap İslam Bilimleri Tarihi I, İstanbul: Kültür Bakanlığı Yayımcılık.

Sezgin, F. (2015b). Müslümanların Coğrafya Tarihine Bugüne Kadar Bilinmeyen İnanılmaz Büyük Katkısı. [Öz]. Fuat Sezgin'in Erciyes Üniversitesi'nde Konferans1, Erciyes Üniversitesi, Kayseri. http://www.tuba.gov.tr/upload/files/fsezgin.pdf (Erişim Tarihi: 01.04.2019).

Sezgin, F. (Şubat, 2016). Tanınmayan Büyük Çağ: Íslam Bilim ve Teknoloji Tarih'inden, İstanbul: Timaş Yayınları.

Sezgin, F. (Mayıs, 2016). Prof. Dr. Fuat Sezgin Öğrencilerle Söyleşi. [Öz]. Prof. Dr. Fuat

Sezgin' in Süleyman Demirel Üniversitesi'nde Söyleşisi, Süleyman Demirel Üniversitesi, Isparta. http://dergipark.gov.tr/download/issue-file/5825 (Erişim Tarihi: 02.04.2019).

Sezgin, F. (Ekim, 2016). Prof. Dr. Fuat Sezgin'in Açılış Dersi. [Öz]. Prof. Dr. Fuat Sezgin'in İstanbul Üniversitesi'nde Verdiği Açılış Dersi, İstanbul Üniversitesi, İstanbul. http://www.ibtav.org/userfiles/file/fuat_sezgin_istanbul_uni_konusma.pdf (Erişim Tarihi: 03.04.2019).

Schoeler, G. (1997). Writing And Publishing On The Use And Function Of Writing In The First Centuries Of Islam, Arabica, 44(3): 423-435.

Şengör, C. (2004). Fuat Sezgin'in İslam Kültür Dünyasının Bilimler Tarihindeki Yeri Konferansı İçinde: Açıllı̧ Konuşması, Ankara: Semih Matbaacılık.

Yıldırım, C. (2012). Bilim Tarihi, İstanbul: Remzi Kitapevi. 